\title{
Resedimented Limestones in Middle and Upper Jurassic Succession of the Slovenian Basin
}

\section{Presedimentirani apnenci v srednje in zgornjejurskem zaporedju Slovenskega bazena}

\author{
Boštjan ROŽIČ $\check{C}^{1} \&$ Tomislav POPIT ${ }^{2}$ \\ ${ }^{1}$ Oddelek za geologijo, Naravoslovnotehniška fakulteta, Privoz 11, 1000 Ljubljana, \\ Slovenija \\ ${ }^{2}$ Paleontološki inštitut Ivana Rakovca, ZRC SAZU, Novi trg 2, 1000 Ljubljana, Slovenija
}

Key words: Jurassic, Slovenian Basin, resedimented limestones

Ključne besede: Jura, Slovenski bazen, presedimentirani apnenci

\begin{abstract}
The Middle and Upper Jurassic succession of the Slovenian Basin is characterized by pelagic sedimentation of siliceous limestones and radiolarian cherts. In the southern and central part of the basin two packages of resedimented limestones are interbedded within pelagic sediments. The Lower resedimented limestones are lower-middle Bajocian to lower Callovian in age. In the southern part of the basin they form laterally discontinuous sequences composed of limestone breccias, calcarenites and micritic limestone and in the central part of the basin calcarenite intercalations within pelagic beds. They were transported by turbidity currents from highly productive ooidal shoals of the Dinaric Carbonate Platform. The Lower resedimented carbonates correlate with the lower three members of the Travnik Formation in the Bovec Trough and similarly developed but much thicker Vajont Formation in the Belluno Basin. The difference in thickness is interpreted as a consequence of shallow-water and longshore currents on the Dinaric Carbonate Platform that transported platform material towards southwest in the direction of the Belluno Basin. The Upper resedimented limestones are upper Kimmeridgian to lower Tithonian and occur within radiolarian cherts in the upper part of the succession as calcarenite beds that originated by turbidity currents. Onset of resedimentation coincides with the emersion-related demise of barrier reef and following deposition of micritic and rare oolitic limestones on the Dinaric Carbonate Platform. Approximatelly coeval resedimented limestones occur in the fourth member of the Travnik Formation in the Bovec Trough, but are not reported from the Ammonitico Rosso Superiore Formation in the Belluno Basin.
\end{abstract}

\section{Kratka vsebina}

Srednje in zgornje jursko zaporedje Slovenskega bazena označuje prevladujoča pelagična sedimentacija okremenjenih apnencev in radiolarijskih rožencev. V južnem in srednjem delu bazena se med pelagičnimi plastmi pojavljata dva nivoja presedimentiranih apnencev. Spodnji presedimentirani apnenci so odloženi v srednjem delu zaporedja in so spodnje ali srednjebajocijske do spodnjecalovijske starosti. V južnem delu bazena tvorijo lateralno prekinjene apnenčeve horizonte, ki jih sestavljajo apnenčeve breče, kalkareniti in mikritni apnenci. V srednjem delu bazena pa se pojavljajo kot posamezne kalkarenitne plasti okoli meje med okremenjenimi apnenci in radiolarijskimi roženci. Ti apnenci so nastali s presedimentacijo materiala s turbiditnimi tokovi iz visoko produktivnih ooidnih plitvin Dinarske karbonatne platforme. Spodnje presedimentirane apnence koreliramo s spodnjimi tremi členi Travniške formacije v Bovškem jarku in podobno razvito, vendar mnogo debelejšo Vajont formacijo v Belluno bazenu. Razlike v debeline so predvidoma nastale kot posledica plitvovodnih tokov na Dinarski karbonatni platformi, ki so transportirali platformski material proti jugozahodu v smeri Belluno bazena. Zgornji presedimentirani apnenci so zgornjekimmeridgijske do spodnjetithonijske starosti in se pojavljajo med radiolarijskimi roženci v zgornjem delu obravnavanega zaporedja kot kalkarenitne plasti nastale s turbiditnimi tokovi. Začetek presedimentacije sovpada s pozno kimmeridgijsko prekinitvijo rasti bariernih grebenov in tej sledečo sedimentacijo mikritnih in redkeje oolitnih apnencev na Dinarski karbonatni platformi. Približno sočasni presedimentirani apnenci se pojavljajo tudi v četrtem členu Travniške formacije v Bovškem jarku, vendar pa niso omenjeni v Ammonitico Rosso Superiore formaciji v Belluno bazenu. 


\section{Introduction}

The investigated succession of the Slovenian Basin is located in the northwestern Slovenia (Fig. 1). The Slovenian Basin deepened at the end of the Triassic and beginning of the Jurassic (Buser, 1989, 1996). The deepening was a consequence of accelerated subsidence caused by rifting-related extensional tectonics characteristic of the southern Tethyan passive continental margin during this period (Winterer \& Bosellini, 1981; Bertotti, 1991; Bertotti et al., 1993; Martire, 1992, 1996; Winterer, 1998; Sarti et al., 1993; Clari \& Masetti, 2002). Westward, in Italy, the rifting event fragmented relatively uniform Upper Triassic carbonate platform and from east to west the following paleogeographic domains formed: the Dinaric (Friuli in Italian literature) Carbonate Platform, the Belluno Basin and the Trento Carbonate Platform (Bosellini et al, 1981; Sarti et al., 1993; Clari \& Masetti, 2002). A similar spatial distribu-

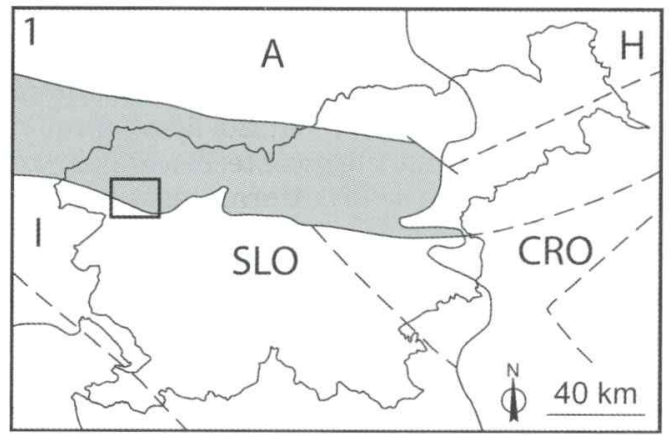

Figure 1. Location and macrotectonic emplacement of investigated area. Southern Alps are shaded gray (after Placer, 1999).

tion of paleogeographic units is observed in western Slovenia, where the Dinaric Carbonate Platform was followed towards the north by the Slovenian Basin and the Julian Carbonate Platform (Fig. 2). During the Early Jurassic Trento and Julian Carbonate Platforms drowned and became pelagic pla-

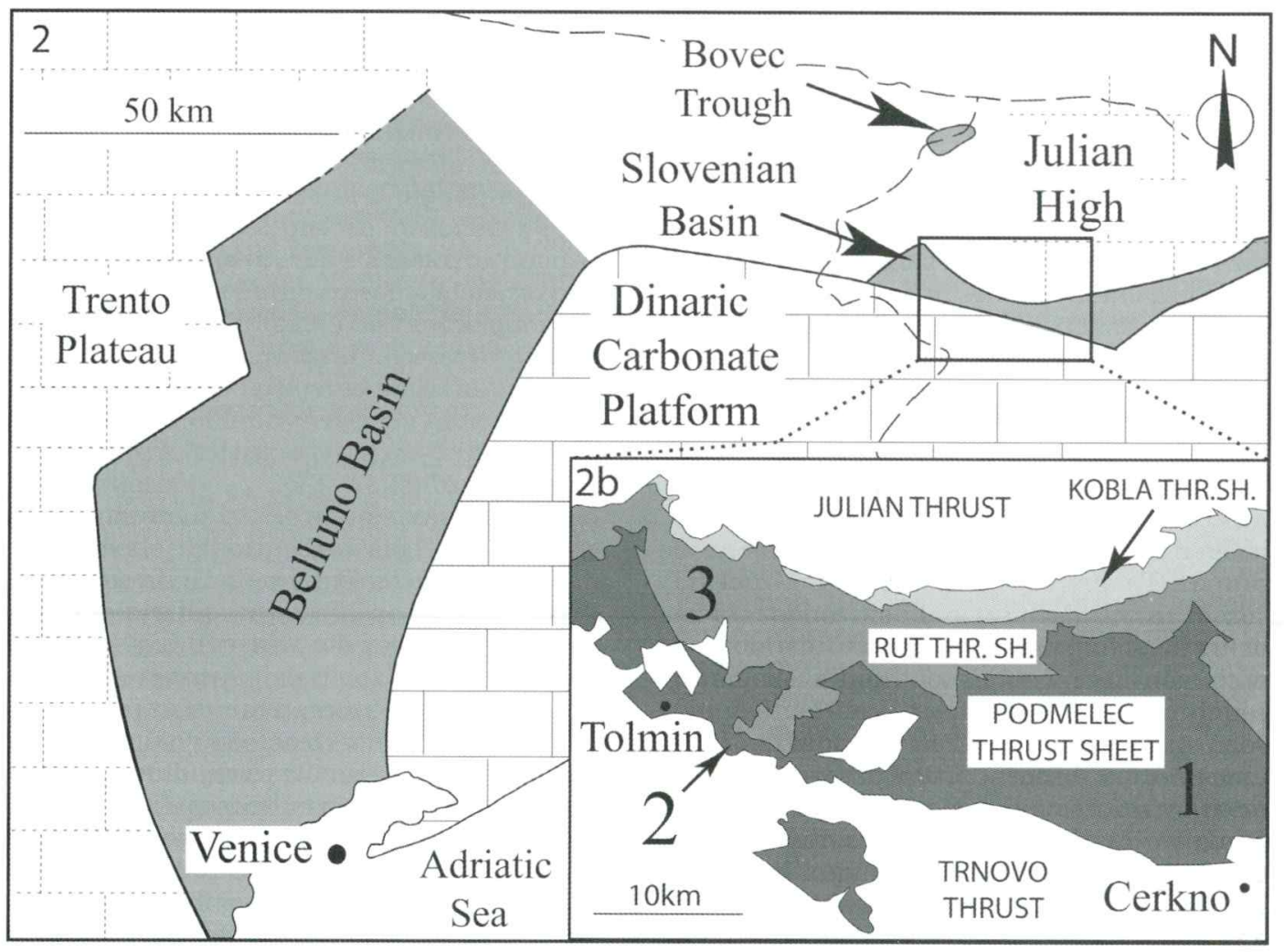

Figure 2. Present-day distribution of paleogeographic units (compiled from Bosellini et al., 1981; Martire, 1992; Buser, 1989 \& Placer, 1999). 1b: Structural map of investigated area (compiled from Buser, 1987 \& Placer, 1999) with locations of studied sections; 1 Zapoškar, 2 Poljubinj, 3 Perbla. 
teaus known as Trento Plateau and Julian High (Clari \& Masetti, 2002; Martire et al., 2006; Buser, 1989, 1996; Jurkovšek et al., 1990; Šmuc, 2004, 2005; Ogorelec et al., 2006). The northeastern area of the Julian Carbonate Platform experienced stronger subsidence and deeper Bovec Trough formed (Šmuc, 2005). Simultaneously the Dinaric Carbonate Platform remained the largest and most stable shallow-water environment in the Mediterranean Tethys throughout all the Jurassic (Vlahović et al., 2005 and references therein). Margins of the Dinaric Carbonate Platform represented the source area for resedimented limestones deposited in the Middle and Upper Jurassic successions of the adjacent Belluno and Slovenian basins. Whereas successions characterized by resedimented limestones are well known in the Belluno Basin (Bosellini et al., 1981; Zempolich \& Erba, 1999; Clari \& Masetti, 2002) they remain very poorly investigated in the Slovenian Basin (Cousin, 1970, 1981; Rožič, 2003a, b). Therefore three sections (Poljubinj, Zapoškar and Perbla) were recently studied in detail. The aim of this paper is:

1. to describe the geometry and facies associations of resedimented limestones and to establish a relative distance of these three sections from the source area,

2. to correlate the investigated sections with the successions from the northern margin of the Dinaric Carbonate Platform, the Bovec Trough and the Belluno Basin.

\section{Geological setting}

In the aspect of macrotectonic subdivision of Slovenia (Placer, 1999) the successions of the Slovenian Basin structurally belong to the Tolmin Nappe which together with the overlying Julian Nappe with successions of the Julian Carbonate Platform represents eastern continuation of the Southern Alps (Fig. 1). The Tolmin Nappe overlies the Trnovo Nappe of the External Dinarides where successions of the Dinaric Carbonate Platform are placed. In the transitional area between the External Dinarides and the Southern Alps, which includes also the southern parts of the Tolmin Nappe, two thrusting phases were recognized. The NE to SW thrusting of the Dinaric phase ended at the end of the Eocene and was overprinted by middle to late Oligocene Southalpine phase characterized by $\mathrm{N}$ to $\mathrm{S}$ thrusting (Placer \& Čar, 1998; Placer, 1999). In general, The Tolmin Nappe can be subdivided in three second-order thrust sheets (Buser, 1986, 1987): the lowest Podmelec Thrust sheet is overthrust by the middle Rut Thrust sheet and the highest Kobla Thrust sheet. The successions of the Slovenian Basin that are most proximal in aspect to the Dinaric Carbonate Platform are located in the Podmelec Thrust sheet and became more distal in the Rut Thrust sheet and finally the Kobla Thrust sheet (Fig. 2b).

The overall Jurassic succession of the Slovenian Basin begins with the lower to middle Liassic Krikov Formation characterized by resedimented and hemipelagic limestones. It is overlain by the Toarcian Perbla Formation composed of black shales to marls, marly limestones and rare beds of resedimented limestones (Cousin, 1973, 1981). The Perbla Formation passes upwards in the Tolmin formation (at present informal name proposed by Rožič, 2006), which is divided in Aalenian to Bajocian lower member characterized by siliceous limestones, and Bajocian to lower Tithonian upper member composed predominantly of radiolarian cherts. Within pelagic deposits of the Tolmin formation resedimented limestones discussed in this paper are locally abundant in the Podmelec Thrust sheet, but appear also as interbeds in the Rut Thrust sheet (Fig. 3). The Jurassic succession ends with the upper Tithonian to Neocomian Biancone Formation (Cousin, 1981; Buser, 1987).

\section{Description of studied sections}

Three sections were studied. In the Podmelec Thrust sheet the Zapoškar and the Poljubinj sections are located. The Zapoškar section is located three kilometers north of Cerkno in a gorge on the southern slopes of Mt. Porezen near the abandoned Zapoškar farm ( $\mathrm{x}=113600, \mathrm{y}=421150)$. The Poljubinj section is located two kilometers southeast of Tolmin in the western slopes of Mt. Kuk near the Poljubinj village $(\mathrm{x}=115550, \mathrm{y}=$ 404500). The Perbla section structurally belongs to the Rut Thrust sheet and is located five kilometers northeast of Tolmin in the Jelovšček gorge near the Perbla village ( $\mathrm{x}=$ $120800, y=404450$ ). 


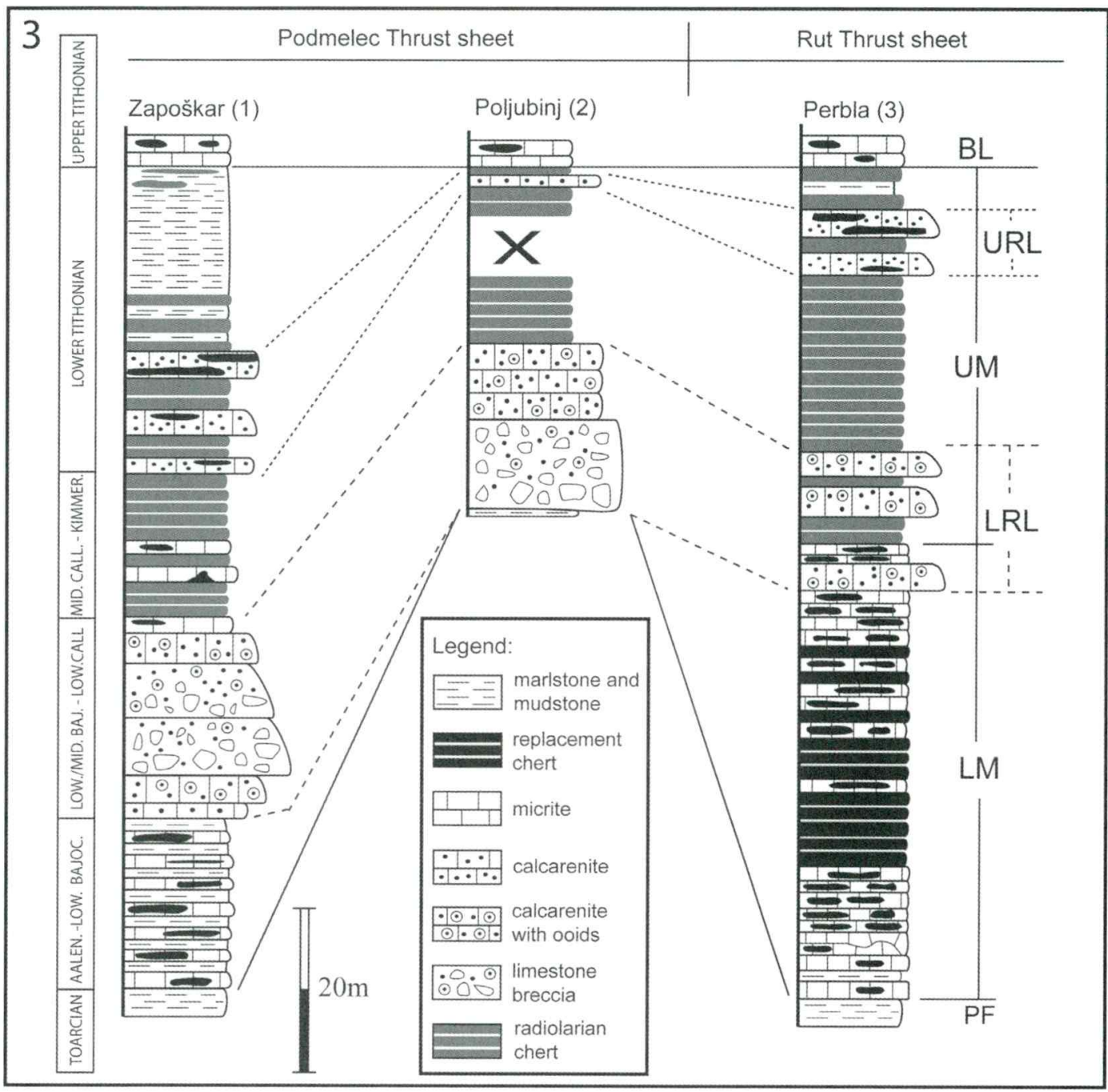

Figure 3. The Tolmin formation in the studied sections; PF Perbla Formation, LM Lower member, UM Upper member, LRL lower resedimented limestones, URL upper resedimented limestones, BL Biancone Limestone.

\section{Background sediments}

The base of the sections is represented by the Perbla Formation composed predominantly of marls (Fig. 3). The Perbla Formation gradually passes into the Tolmin formation, which is divided in two members. The lower member consists of dark gray siliceous limestones of wackestone type with calcified radiolarians and sponge spicules. In the Zapoškar section marls are common within siliceous limestones through the entire member. In the Perbla section the silicification is locally very strong and beds of black cherts are observed in the middle part of the member. Cherts exhibit similar microfacies as siliceous limestones but are composed of microcrystalline quartz. In the Poljubinj section the lower member of the Tolmin formation is missing. The upper member of the formation is present in all sections and is represented by radiolarian cherts that are colored greenish-gray in the lower part and violet-red in the upper part of the member. The composition corresponds to black cherts described in the lower member of the Tolmin formation in the Perbla section. In the upper part of the upper member marls and 
shales are common. In the Zapoškar section the upper part of the member is composed almost exclusively of marls. Within the Tolmin formation two packages of resedimented limestones are distinguished (Fig. 3).

\section{Lower resedimented limestones}

Lower resedimented limestones in the Zapoškar and Poljubinj sections are amalgamated sequences (Fig. 4). In the Zapoškar section the lower resedimented limestones are 25 meters thick and placed between two members of the Tolmin formation. They are composed of bedded limestone breccias, calcarenites and rare beds of micrite. Calcarenites are bedded (10 to $180 \mathrm{~cm}$ ), gray, usually graded and parallel laminated. Microfacies is predominantly grainstone composed of peloids, micritized ooids, shallow-water and basinal intraclasts and fossils, predominantly echinoderms and rarer benthic foraminifers, bivalve and brachiopod shells and bryozoan fragments (Pl. 1, Fig. 1). As suggested by rounded circular shape, a large portion of peloids probably represents strongly micritized ooids. Dark gray, fine-grained, wavy and cross laminated grainstone and packestone occur in the upper parts of graded or thin-bedded (up to $20 \mathrm{~cm}$ ) calcarenites. Grains are pellets to peloids and bioclasts, predominantly echinoderms, calcified radiolarians and rare small benthic foraminifers (Pl. 1, Fig. 2). Cements in grainstones are mosaic and syntaxial around echinoderms. In the lower and upper part of the package nodules of replacement chert are observed in calcarenites. The finest beds are darkgray, poorly bioturbated, wavy laminated wackestones and mudstones. Among allochemes calcified radiolarians and sponge spicules prevail. In bioturbated borings pellets are common. Breccias occur at the base of thick (up to $4 \mathrm{~m}$ ) beds. Beds are graded and breccias upward gradually turn into calcarenites. Previously they were described as one thick $(17 \mathrm{~m})$ graded breccia bed (Rožič, 2003a, b), but detailed work revealed that this package is composed of five smaller amalgamated sequences, where breccias appear only in the lower two. Microfacies of breccias is rudstone and two major clast types (up to $5 \mathrm{~cm}$ large) are differentiated. The composition of deep-water intraclasts corresponds to the pelagic limestones described above. Shallow-water clasts are grainstones and rarely packstones composed of peloids, ooids, intraclasts and bioclasts, mostly echinoderms and rare benthic foraminifers. In grainstone clasts rim and mosaic cements are observed. Matrix in breccias is earlier described grainstone. Resedimented limestones in this area laterally wedge out and in the western slopes of Mt. Porezen radiolarian cherts directly overlie siliceous limestones (Rožič, 2006).

In the Poljubinj section the lower resedimented limestones are 20 meters thick and overlie with erosional contact the marls of the Perbla Formation (Fig. 4). The package begins with up to 11 meters thick, massive and channeled breccia megabed. The composition of breccia corresponds to that described in the Zapoškar section (Pl. 1, Fig. 3 ) but contains also rare chert clasts. It is overlain by two dark gray, coarse-grained packstone beds ( 7 to $8 \mathrm{~cm}$ ), each covered by wavy laminated wackestone bed $(10 \mathrm{~cm})$. Packestone is composed of the same material as grainstone in the Zapoškar section but clasts are more abundant (Pl. 1, Fig. 4, 4b). In wackestone thin-shelled bivalves and spicules prevail and are oriented parallel to the bedding. The upper part of the resedimented limestones is composed of bedded (10 to 90 $\mathrm{cm}$ ), structure-less, coarse-to-medium-grained grainstone. Its composition is similar to the grainstone of the Zapoškar section, but contains more ooids. A 2,5 meters thick bed with no apparent internal bedding stands out. It is slightly coarser and includes thin chert lenses.

In the Perbla section lower resedimeted limestones appear as isolated, graded, parallel and rarely cross-laminated calcarenite beds $(10$ to $50 \mathrm{~cm}$ ) within the pelagic succesion around the boundary between the two members of the Tolmin formation (Fig. 4). Texture and composition of coarse-tomedium-grained grainstone are the same as in the calcarenites of the Zapoškar section (Pl. 2, Fig. 1,2). Ooids are more abundant and, if larger, also micritized. Fine-grained calcarenites are also packestones composed as those from the Zapoškar section. Beds are partially replaced by nodular chert.

Lower-middle Bajocian to Lower Callovian age of the lower resedimented limestones was determined with foraminifers and radiolarians. Middle Jurassic foraminiferas were determined by Gušić (personal communication, 2006): Protopeneroplis striata (Weynschenk) (Pl. 1, Fig. 4b) in the Zapoškar and Poljubinj sections, Protopeneroplis sp. 


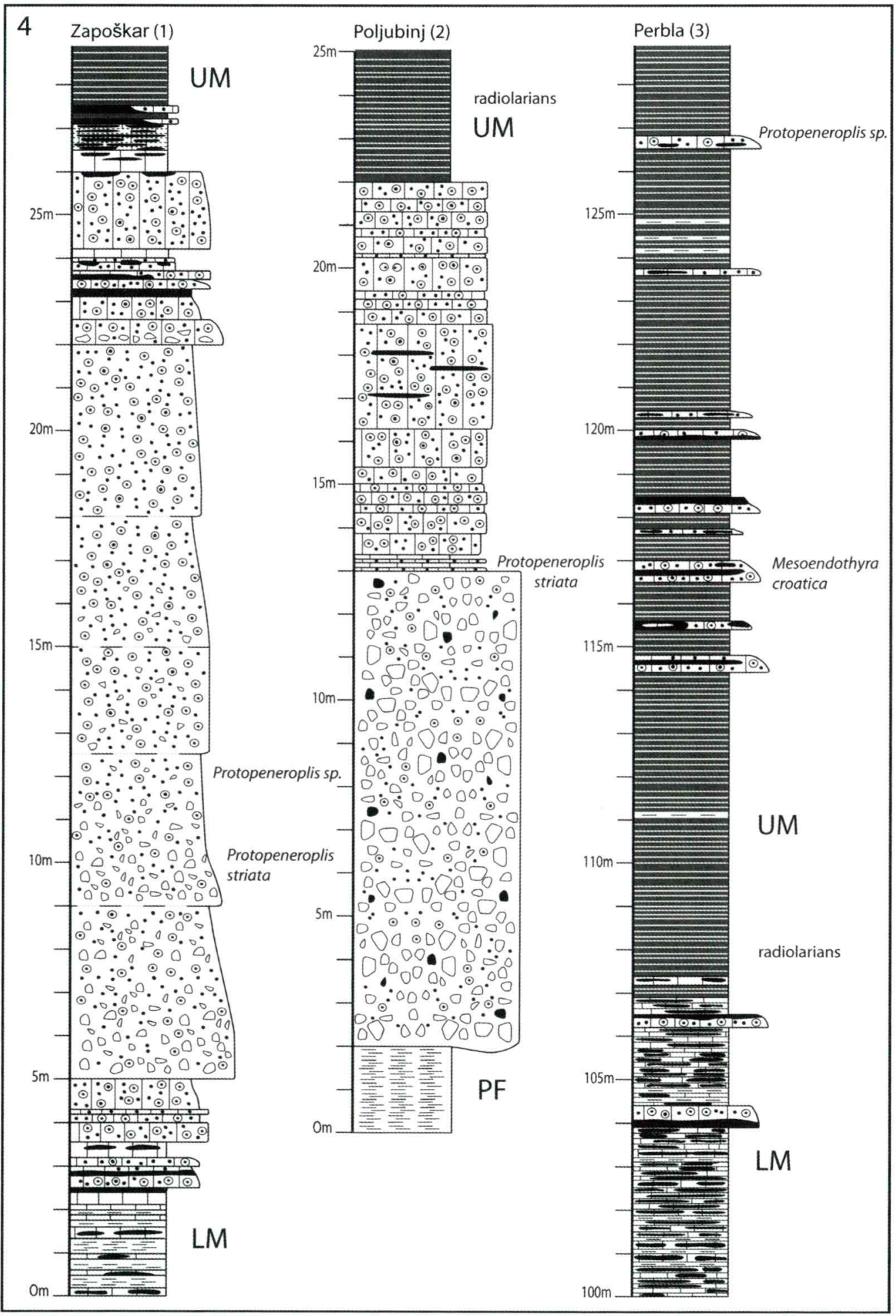

Figure 4. Detailed sections of the lower resedimented limestones (for legend and abbreviations see fig. 2). 
in the Zapoškar and Perbla sections and $M e$ soendothyra croatica (Gušić) (Pl. 2, Fig. 2) in the Perbla section. The oldest resedimented limestones in the Perbla section occur 4 meters below a radiolarian sample, assignable to lower - middle Bajocian (UAZone 3-4 of Baumgartner et al., 1995; in Goričan et al., 2006). In the Poljubinj section a radiolarian sample 2 meters above the boundary with resedimented limestones was dated as middle Callovian - lower Oxfordian (UAZone 8 of Baumgartner et al., 1995; in Goričan et al., 2006).

Sedimentary structures in limestones indicate a deposition by gravity flows, mostly by turbidity currents. Massive, channelized breccia megabed in the Poljubinj section was deposited either by a debris flow or a high-density turbidity current. Overlying packstone and wackestone beds are probably genetically related to the megabed and therefore represent a two-pulsed upper part of a two-component gravity flow (Mullins \& Cook, 1986; Mutti, 1992). Nevertheless, these beds could also originate as separated turbidites. Massive structure in calcarenite beds observed especially in the upper part of the resedimented limestones in the Poljubinj section could indicate deposition by modified grain flows or sandy debris flows (Stow \& Johansson, 2000; Shanmugam, $2000)$. But we presume that the deposition by turbidity current is more probable and that the massive structure is a consequence of pre-sorting of the material in a source area. The distribution of facies associations where the thickness, abundance, and grain-size of resedimented limestones decrease from south to north proves a south-lying source area. The composition of resedimented limestones, especially calcarenites indicates that the source area of the resedimented material were ooidal shoals on the northern margin of the Dinaric Carbonate Platform. Breccia clasts indicate an erosion of approximately coeval platform limestones as well as slope or basinal limestones. The lower resedimented limestones are discontinuous in the Podmelec Thrust sheet. In the Zapoškar area the resedimented limestones thin and finally wedge out towards the west. In the Poljubinj section the resedimented material filled a channel. Since the horizon cuts directly into marls of the Perbla Formation (siliceous limestones of the Tolmin formation are missing) the erosion of older basinal strata is evidenced.

\section{Upper resedimented limestones}

Resedimented limestones reappear as calcarenite intercalations within radiolarian cherts in the uppermost part of the Tolmin formation (Fig. 5). In the Zapoškar section beds are 10 to $140 \mathrm{~cm}$ thick, graded and parallel laminated. Thicker beds are gray, coarse-to- medium-grained grainstones composed predominantly of diverse limestone clasts, fossils and very rare ooids. Clasts of shallow-water origin are mostly grainstones composed of peloids, intraclasts and pellets (Pl. 2, Fig. 3). Mudstone clasts are common. Some are well rounded and are better classified as peloids, whereas others contain calcified radiolarians and are therefore pelagic intraclasts. Fossils are diverse but the most abundant are still echinoderms (Pl. 2, Fig. 4, ). Others bioclasts are benthic foraminifers, bryozoan fragments, bivalves, brachiopods and rare stromatoporid and dasycladacean fragments. Cements are mosaic and syntaxial around echinoderms. Especially in the lower and upper margins of beds grainstones are replaced by nodular chert. Thinner limestone beds (10 to $20 \mathrm{~cm}$ ) are dark gray, finegrained, rarely graded and parallel or wavy laminated grainstones and packestones to wackestones composed of calcified radiolarians, echinoderms, rare benthic foraminifers, micritic intraclasts and/or pellets ( $\mathrm{Pl}$. 2, Fig. 5). This microfacies are replaced by chert nodules as well. Similar rare limestone beds occur also in the lower and middle part of radiolarian cherts. Above the last thick calcarenite bed marls gradually prevail over radiolarian cherts and compose the upper 20 meters of the Tolmin formation. Chert beds and lenses reappear in the uppermost 2 meters of the Tolmin formation.

In the Poljubinj section upper resedimented limestones are represented only by two thin $(10 \mathrm{~cm})$, medium-grained grainstone beds of similar composition as those described in the Zapoškar section (Fig. 5).

In the Perbla section limestone beds (10 to $90 \mathrm{~cm}$ ) are quite abundant (Fig. 5). They occur as intercalations between radiolarian cherts in the upper 10 meters of the Tolmin formation, but thicker and coarser calcarenite beds are present only in the uppermost 5 meters. Although graded and parallel laminated grainstones prevail, packstones and wackestones are also present in thinner beds. Composition generally corresponds to the microfacies described in the Zapoškar 


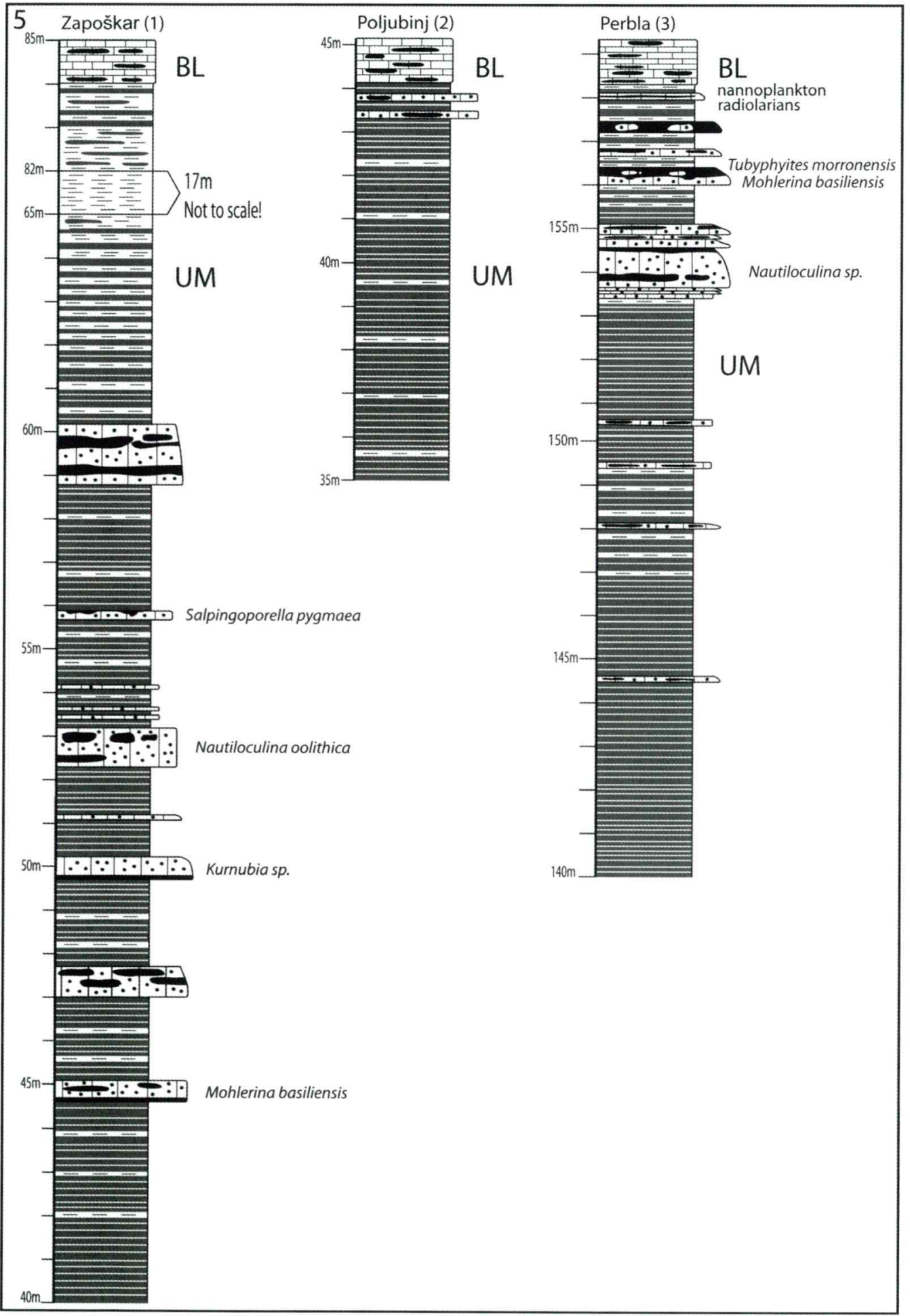

Figure 5. Detailed sections of the upper resedimented limestones (for legend and abbreviations see fig. 2). 
section (Pl. 2, Fig. 6), but rare aptychi and Saccocoma fragments were also observed in the uppermost beds.

Late Kimmeridgian to Lower Tithonian age of the upper resedimented limestones was determined by foraminifers, dasycladaceas, radiolarians and nannoplankton. From the Upper Jurassic foraminifers stratigraphically important were determined (Gušić, personal communication): Mohlerina basiliensis (Mohler), Nautiloculina oolithica (Mohler). (Pl. 2, Fig. 4), and Kurnubia sp. in the Zapoškar section and Mohlerina basiliensis (Pl. 2, Fig. 6), Nautiloculina sp. and Tubyphyites morronensis (Crescenti) in the Perbla section. In the Zapoškar section also the Upper Jurassic (Gušić, personal communication) dasycladacea Salpingoporella pygmaea (Gümbel) was found. Cessation of resedimented limestones coincides with the boundary between the Tolmin and the Biancone formations which was dated with radiolarians and nannoplankton in the lower/ upper Tithonian (Goričan et al., 2006). The lower boundary is less successfully dated, but is probably of late Kimmeridgian - early Tithonian age, since resedimented limestones occur only in the uppermost part of the Tolmin formation.

Sedimentary structures in resedimented limestones suggest a deposition by turbidity currents. Although no apparent differences of facies associations are observed between the successions in the Podmelec and the Rut Thrust sheets we are still able to determine a southward source area of resedimented limestones, because limestone beds are absent in the Upper Jurassic successions of the northernmost Kobla Thrust sheet (Rožič, 2006). The composition of resedimented limestones indicates a shallow-water sedimentary environment exceedingly different from ooidal shoals described as the source area for the lower resedimented limestones. Composition comparison with the lower resedimented limestones elucidates that the late Jurassic Dinaric Carbonate Platform provided smaller amounts of ooids, but more abundant shallow-water intraclasts and more diverse fossils. Simultaneously with the resedimentation of the platform material an increased terrigenous input is observed. Terrigenous deposits are especially abundant in the Zapoškar section where marl forms the upper 20 meters of the Tolmin formation. It is presumably related with a more warm and humid climate in the Late Jurassic. Such climatic conditions increased the erosion of continental areas and consequently the transport of clay material into basins (e.g. Weissert \& Mohr, 1996; Picard et al., 2002).

In the Zapoškar section resedimented limestones exceptionally occur also in the lower and middle part of radiolarian cherts. Beds are thin and represented predominantly by packstones to wackestones composed of echinoderms, micritic intraclasts and calcified radiolarians. For these beds we propose a slope as a source area of apparently gravity-displaced limestone material.

\section{Correlation with the Dinaric Carbonate Platform, the Bovec Trough and the Belluno Basin}

Within the Middle and Upper Jurassic Tolmin formation of the Slovenian Basin two packages of resedimented limestones were recognized (Fig. 6). The composition of the lower resedimented limestones reflects sedimentary conditions on the Dinaric Carbonate Platform, which in the Middle Jurassic was a highly productive open carbonate shelf (Orehek \& Ogorelec, 1978, Bosellini et al., 1981), where large masses of ooids and peloids were formed (the formation Oolith des Trnowaner Waldes; Kossmat, 1906). Thickness of this formation is up to 700 meters (Buser, 1986). The exceeding material that originated during maximal carbonate productivity between lower - middle Bajocian to lower Callovian was exported from platform margins to proximal parts of the Slovenian Basin. The redeposition was mainly with turbidity currents that also eroded platform, slope and basinal limestones. The lower horizon is correlated with the upper Bajocian to Bathonian lower three members of the Travnik Formation from the Bovec Trough (Šmuc, 2005; Šmuc \& Goričan, 2005) and Vajont Limestone from the Belluno Basin also assigned to late Bajocian and Bathonian (Cobianchi, 2002; Clari \& Masetti, 2002) (Fig. 6). The composition of resedimented limestones is generally similar in three correlated paleogeographic domains, but a great difference occurs when thicknesses are compared (Fig. 7). In the Slovenian Basin lower resedimented limestones are only up to 25 meters thick. On the other hand, in the Belluno Basin the Vajont Limestone reaches 600 meters in proximal parts, but decreases 


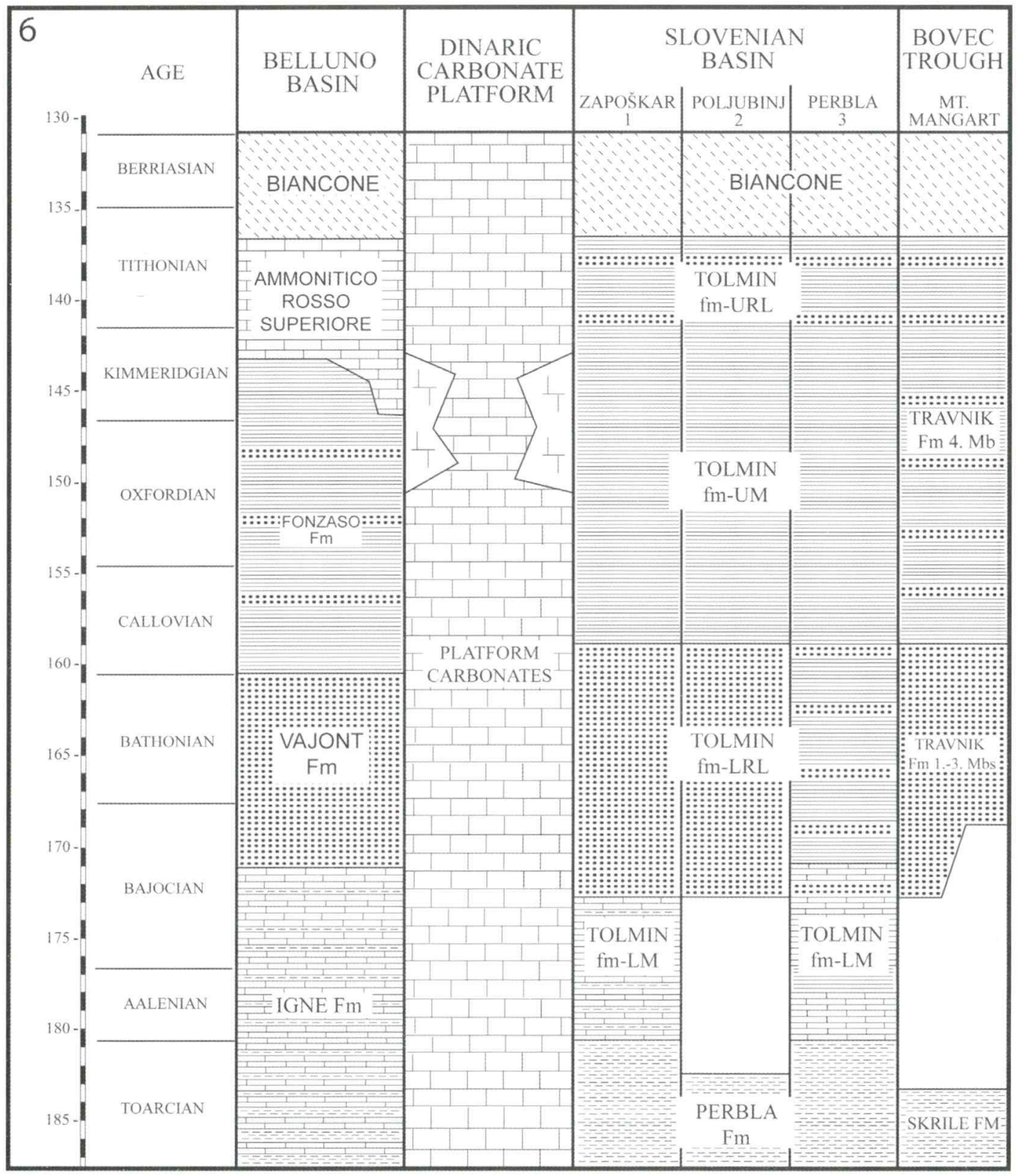

Figure 6. The correlation of investigated sections of the Slovenian Basin with formations of the Belluno Basin (compiled after Baumgartner, 1985; Clari \& Masetti, 2002; Cobianchi, 2002) and the Bovec Trough (after S Smuc, 2005). Resedimented limestones are marked with dotted pattern. Time scale after Odin (1994). Abbreviations in the Tolmin formation are the same as used in fig. 2.

in thickness basinward. A decrease is also observed within the proximal areas of the Belluno Basin in the northeast direction towards the Slovenian Basin (B o sellini et al., 1981; Zempolich \& Erba, 1999, Clari \& Masetti, 2002). The difference in thickness within the Belluno Basin was interpreted as a consequence of a transport of the material on the Dinaric Carbonate Platform towards the southwest caused by shallow-water and longshore currents that were probably induced by permanent winds (Bosellini et al., 


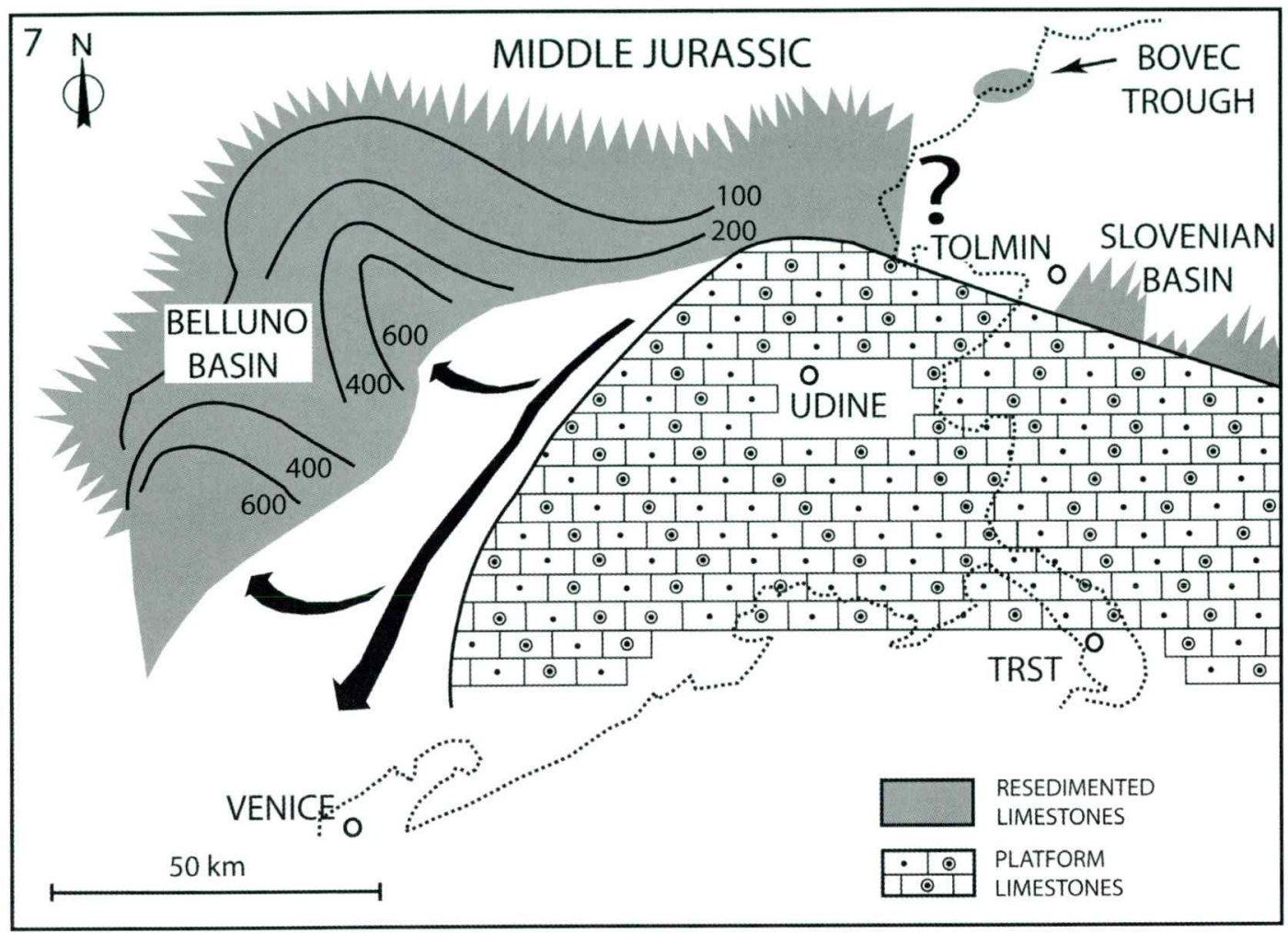

Figure 7. The distribution of thickness of resedimented limestones at the end of Bathonian as a consequence of windward position of Slovenian Basin and leeward position of the Belluno Basin in aspect to the Dinaric Carbonate Platform (modified after Bosellini et al., 1981). The thickness of Vajont Limestone is shown with isopachs. Maximal thickness of resedimented limestones in Slovenian Basin is 25 meters and in the Bovec Trough 90 meters (after Šmuc, 2005).

1981; Wright \& Bruchette, 1996). Newly contributed data from the Slovenian Basin confirms such interpretation that locates Slovenian Basin on the windward side of the Dinaric Carbonate Platform which starved from resedimented shallow-water material. The lower three members of the Travnik Formation from Bovec Trough studied in the Mt. Mangart area are 47 to 90 meters thick (Šmuc, 2005; Šmuc \& Goričan, 2005). The Bovec Trough could therefore represent a link between the Slovenian and the Belluno basins but this is questionable since the exact paleogeographic location of succession from Mt. Mangart area is not satisfactorily resolved.

The resedimentation of shallow-water material in the Slovenian Basin ceased during the Callovian and was scarce until late Kimmeridgian. During this period the northern margin of the Dinaric Carbonate Platform was first drowned and thinbedded micritic limestone and calcarenite with chert nodules deposited (Buser, 1978, 1986). This correlation is not certain, because limestones with cherts of the Dinaric Carbonate Platform are poorly dated. In the late Oxfordian the Dinaric Carbonate Platform became rimmed by barrier reef (Turnšek, 1997) (Fig. 6). From this time only in the Zapoškar section rare resedimented limestones with slope as a source area are known. At the end of the Kimmeridginan large areas of the Dinaric Carbonate Platform became subaerially exposed (Dozet, 1994; Dozet et al., 1996; Tišljar et al., 2002) which lead to the demise of barrier reefs (Turnšek, 1997). The reestablishment of sedimentation followed in the latest Kimmeridgian or early Tithonian, when bedded micritic limestones and rare oolitic limestones with Clypeina jurassica (Favre) started to deposit (Buser, 1986). The described change of sedimentation on the Dinaric Carbonate Platform is recorded with the onset of deposition of upper resedimented limestones in 
the Slovenian Basin. It is necessary to consider that especially in the Zapoškar section upper resedimented limestones could be older and marly top of the section would form with the dispersal of terigenous material from emerged areas of the Dinaric Carbonate Platform. But a very small amount of reef-building fossils in platform-derived material in resedimented limestones denies such interpretation. Resedimented limestones are reported also in the upper part of the Callovian to lower Tithonian fourth member of the Travnik Formation in the Bovec Trough (Šmuc, 2005; Šmuc \& Goričan, 2005) (Fig. 6). Upper Kimmeridgian to lower Tithonian of the Belluno Basin is represented by the Ammonitico Rosso Superiore Formation that is free of resedimented limestones (Fig. 6). But they occur in proximal parts of the Belluno Basin in the Fonzaso Formation that is otherwise characterized by siliceous pelagic sedimentation (Clari \& Masetti, 2002; Cobianchi, 2002). These resedimented limestones are older and therefore not correlatable with upper resedimented limestones of the Slovenian Basin.

\section{Conclusions}

The Middle and Upper Jurassic succession of the Slovenian Basin is characterized by the Tolmin formation that conformably overlies the marls of the Toarcian Perbla Formation. The Tolmin formation is divided in two members. The lower member is composed predominantly of siliceous limestones and rare cherts, whereas the upper member consists almost entirely of radiolarian cherts. In the southern and central part of the basin resedimented limestones are common and are divided in two packages. Lower resedimented limestones are lowermiddle Bajocian to lower Callovian in age. In the Podmelec Thrust sheet, which paleogeographically corresponds to the southern part of the basin, lower resedimented limestones form up to 25 meters thick limestone packages deposited either discomformably over the Perbla Formation or conformably over the lower member of the Tolmin formation. In the Rut Thrust sheet where successions of the central part of the basin are found lower resedimented limestones occur as calcarenite intercalations within pelagic beds around the boundary between two members of the Tolmin formation. Resedimented limestones were deposited mostly by turbidity currents. They are represented predominantly by coarse-to-medium-grained grainestones composed of peloids, micritized ooids, shallow-water and basinal intraclasts and fossils, predominantly echinoderms. Other microfacies are fine-grained grainstone and packestone composed of pellets to peloids and bioclasts, predominantly echinoderms and wackestones to mudstones with calcified radiolarians and sponge spicules. In the southern part of the basin thick-bedded limestone breccias are common. The texture is rudstone with grainstone matrix. Clasts are deep-water intraclasts and eroded coeval shallow-water clasts composed similary as grainstone matrix of the breccias. From the described distribution of facies associations and composition of resedimented limestone we can conclude that during the early-middle Bajocian to early Callovian limestone material that originated in ooidal shoals in the northern margin of the Dinaric Carbonate Platform was redeposited predominantly by turbidity currents into the proximal-southern parts of the Slovenian Basin. Lower resedimented limestones correlate with the lower three members of the Travnik Formation from the Bovec Trough and the Vajont Formation from the Belluno Basin. The overall thickness of resedimented limestones is much smaller in the Slovenian Basin when compared with other two paleogeographic domains. Differences are interpreted as a consequence of southwest-ward transport of the material on the Dinaric Carbonate Platform, induced by shallow-water and longshore currents.

\section{Plate 1}

1 Coarse-grained grainstone with micritized ooids, peloids, and echinoderm fragments, Zapoškar section.

2 Fine-grained grainstone with intraclasts, peloids/pellets and echinoderm fragments, Zapoškar section.

3 Breccia with diverse shallow-water clasts, basinal intraclasts and grainstone matrix, Poljubinj section.

4 Coarse-grained packstone with ooids, peloids, shallow-water clasts and basinal intraclasts, Poljubinj section. 4b. Protopeneropsis striata (Weynschenk) from the same microfacies. 

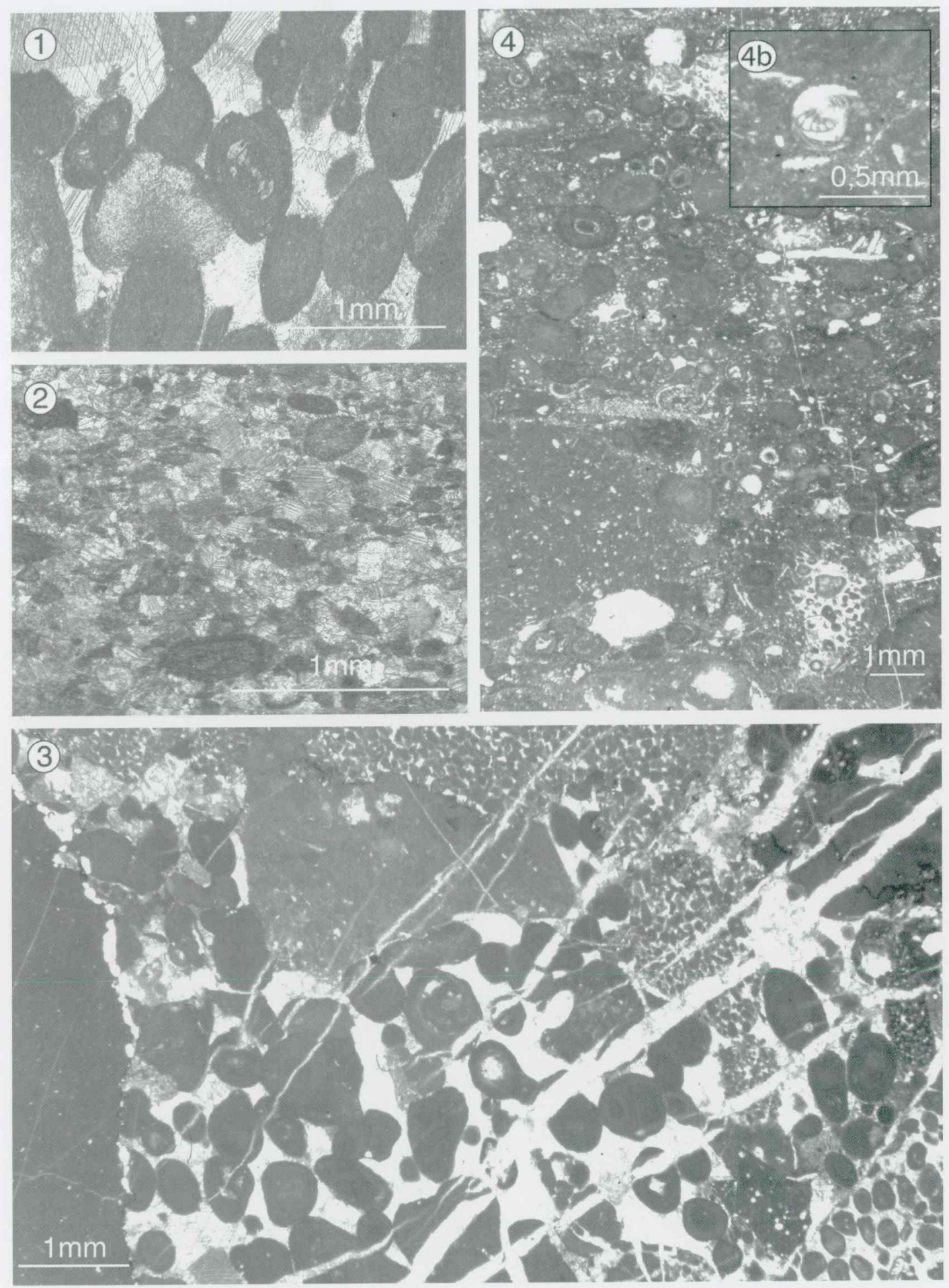
Upper resedimented limestones are late Kimmeridgian to early Tithonian in age and occur as calcarenite intercalations within radiolarian cherts in the upper part of the Tolmin formation. They were sedimented by turbidity currents and are represented predominantly by coarse-to-medium-grained grainstones composed mostly of shallowand deep-water limestone clasts, diverse fossils and very rare ooids. Rarer fine-grained packestones to wackestones also occur. They are composed similarly as grain-size counterparts in the lower resedimented limestones. The upper resedimented limestones deposited after emersion-related demise of barrier reef, which until late Kimmridgian rimmed the Dinaric Carbonate Platform. They are coeval with the following sedimentation of micritic and rare oolitic limestones on the platform. Resedimented limestones are reported also from the approximately coeval fourth member of the Travnik Formation in the Bovec Trough. Resedimented limestones do not occur in the simultaneous Ammonitico Rosso Superiore Formation in the Belluno Basin.

\section{Acknowledgments}

We sincerely thank Ivan Gušić for determinations of foraminifers and dasycladaceas. Špela Goričan is acknowledged for constructive consultations and for reviewing the manuscript. Mateja Perpar is thanked for English correction of the final text.

\section{References}

Baumgartner, P.O., Martire, L., Goričan, S., O'Dogherty, L., Erba, E. \& Pillevuit, A. 1995: New Middle and Upper Jurassic radiolarian assemblages co-occurring with ammonites and nannofossils from the Southern Alps (Northern Italy). in: Baumgartner, P. O., O'Dogherty, L.,
Goričan, S., Urquhart, E., Pillevuit, A. \& De Wever, P. (eds.)- Middle Jurassic to Lower Cretaceous Radiolaria of Tethys: Occurrences, Systematics, Biochronology. Mémoires de Géologie, 23, 737-750, Lausanne.

Bertotti, G. 1991: Early Mesozoic extension and Alpine tectonics in the Western Southern Alps. The geology of the area between Lugano and Menaggio (Lombardy, northern Italy). - Mem. Sci. Geol., 43, 17-123, Padova.

Bertotti, G., Picotti, V., Bernoulli, D. \& Castellarin, A. 1993: From rifting to drifting: tectonic evolution of the South-Alpine upper crust from the Triassic to the Early Cretaceous. - Sedimentary Geology, 86, 53-76, Amsterdam.

Bosellini, A., Masetti, D. \& Sarti, M. 1981: A Jurassic "Tongue of the ocean" infilled with oolitic sands: the Belluno Trough, Venetian Alps, Italy. - Marine Geology, 44, 59-95, Amsterdam.

Buser, S. 1978: Razvoj jurskih plasti Trnovskega gozda, Hrušice in Logaške planote. - Rudarsko - metalurški zbornik, 4, 385- 406, Ljubljana.

Buser, S. 1986: Tolmač k Osnovni geološki karti SFRJ 1: 100000 lista Tolmin in Videm (Udine). - Zvezni geološki zavod, 103 pp., Beograd.

Buser, S. 1987: Osnovna geološka karta SFRJ 1: 100 000, list Tolmin. - Zvezni geološki zavod, Beograd.

Buser, S. 1989: Development of the Dinaric and Julian carbonate platforms and the intermediate Slovenian basin (NW-Yugoslavia). - in: Carulli, G.B., Cucchi, F. \& Radrizzani, C.P. (eds.): Evolution of the Karstic carbonate platform: relation with other periadriatic carbonate platforms. - Mem. Soc. Geol. Ital., 40 (1987), 313-320, Roma.

Buser, S. 1996: Geology of western Slovenia and its paleogeographic evolution. - in: Drobne, K., Goričan, S. \& Kotnik, B. (eds.): The role of Impact Processes in the Geological and Biological Evolution of Planet Earth. - International workshop, ZRC SAZU, 111-123, Ljubljana.

Clari, P. \& Masetti, D. 2002: The Trento Ridge and the Belluno Basin. - in: Santantonio M. (ed.): General Field Trip Guidebook, VI International Symposium on the Jurassic System, 12-22 September 2002, 271-315, Palermo.

Cobianchi, M. 2002: Calcareous Nannofossils from the Middle ans Upper Jurassic of the Belluno Basin (Southern Calcareous Alps). - Atti Ticinensi di Scienze della Terra, 43, 3-24, Pavia.

Cousin, M. 1970: Esquisse géologique des confins italo-yougoslaves: leur place dans les Dinarides et les Alpes méridionales. - Bull. Soc. Géol. France, 12, 1034-1047, Paris.

\section{Plate 2}

1 Medium-grained grainstone with ooids, peloids, micritic intraclasts and rare foraminifers; grains are partially replaced by small quartz crystals, Perbla section.

2 Mesoendothyra croatica (Gušić) in medium-grained grainstone, Perbla section.

3 Shallow-water grainstone clast with peloids and intraclasts lithified with rim and mosaic cements in coarse-grained grainstone, Zapoškar section.

4 Coarse-to-medium-grained grainstone with intraclasts, rare peloids, echinoderm fragments and $\mathrm{Na}$ utiluculina oolithica (Mohler) in the center, Zapoškar section.

5 Fine-grained packstone with calcitified radiolarians, sponge spicules, micritic intraclasts and/or peloids and echinoderm fragments, Zapoškar section.

6 Coarse-to-medium-grained grainstone with intraclasts, peloids, echinoderm fragments, ooids? and Mohlerina basiliensis (Mohler) in the center, Perbla section. 

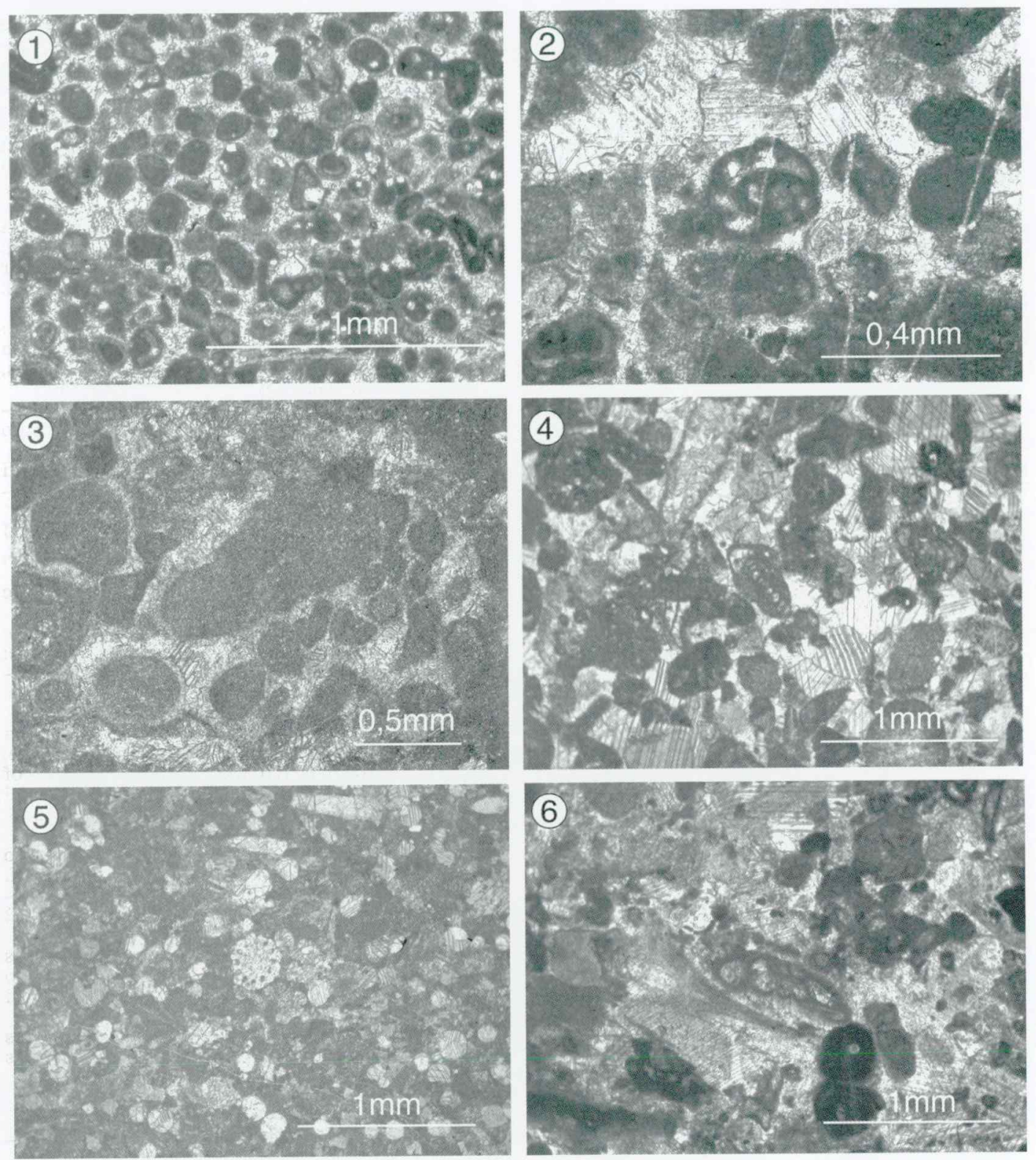
Cousin, M. 1973: Le sillon slovene: les formations triasiques, jurassiques et neocomiennes au Nord - Est de Tolmin (Slovenie occ., Alpes mer.) et leurs affinites dinariques. - Bull. Soc. Géol. France, 7/XV, 326-339, Paris.

Cousin, M. 1981: Les repports Alpes - Dinarides. Les confins de I'talie et de la Yougoslavie. - Sociètè Gèologique du Nord, Publi. 5, 1, 521 pp., 2 - Annexe, 521 pp.

Dozet, S. 1994: Malmian bauxites at Kočevska Reka and Kočevje. - RMZ-materials and geoenvironment. 41, 215-219, Ljubljana.

Dozet, S., Mišič, M. \& Žuža, T. 1996: Malm Bauxite Occurences in Logatec, Nanos and Kocevje area. - RMZ-materials and geoenvironment, 43/1-2, 23-35, Ljubljana.

Goričan, Š., Rožič, B. \& Pavšič, J. 2006: Datacije jurskih radiolarijskih rožencev Tolminskega pokrova. - in: Režun, B., Eržen, U., Petrič, M. \& Gantar., I. (eds.): Zbornik povzetkov (book of abstracts), 2. Slovenski Geološki Kongres, Idrija, 26.-28. September 2006, 178 str., 46-47, Idrija.

Jurkovšek, B., Šribar, L., Ogorelec, B. \& Jurkovšek-Kolar, T., 1990: Pelagic Jurassic and Cretaceous beds in the western part of the Julian Alps. - Geologija, 31/32 (1988/1989), 285-328, Ljubljana.

Kossmat, F. 1906: Das Gebiet zwischen dem Karst und dem Zuge der Julischen Alpen. - Jb. Geol. R.A., 56, Wien.

Martire, L. 1992: Sequence stratigra-phy and condensed pelagic sediments. An example from the Rosso Ammonitico Veronese, northeastern Italy. - Palaeogeogr., Palaeoclim., Palaeoecol., 94, 169-191, Amsterdam.

Martire, L. 1996: Stratigraphy, Facies and Synsedimentary Tectonics in the Jurassic Rosso Ammonitico Veronese (Altopiano di Asiago, NE Italy). - Facies, 35, 209-236, Erlangen.

Mullins, H.T. \& Cook, H.E. 1986: Carbonate Apron Models: Alternatives to the Submarine Fan Model for Paleoenvironmental Analysis and $\mathrm{Hy}-$ drocarbon Exploration. - Sedimentary Geology, 48, 37-79, Amsterdam.

Mutti, E. 1992: Turbidite Sandstones. - 275 pp. Agip.

Odin, G.S. 1994: Geological Time Scale (1994).- C.R. Acad. Sci. Paris, 318/II, 59-71, Paris. Ogorelec, B., Buser, S. \& Mišič, M. 2006: Manganese nodules in Jurassic limestone of the Southern Alps in Slovenia. - Geologija, 49/1, 6984, Ljubljana.

Orehek, A. \& Ogorelec, B. 1980: Sedimentološke značulnosti jurskih in krednih kamenin na Trnovskem gozdu. - Geološki Vjesnik, 32, 185192, Zagreb.

Picard, S., Lecuyer, C., Barrat, J., Garcia, J., Dromart, G. \& Sheppard, S.M.F., 2002: Rare earth element contents of Jurassic fish and reptile teeth and their potential relation to seawater composition (Anglo-Paris Basin, France and England). - Chemical Geology, 186, 1-26.

Placer, L. \& Čar, J. 1998: Struktura Blegoša med Zunanjimi in Notranjimi Dinaridi. - Geologija, 40, 305-323, Ljubljana.

Placer, L. 1999: Contribution to the macrotectonic subdivision of the border region between Southern Alps and External Dinarides. - Geologija, 41 (1998), 223-255, Ljubljana.

Rožič, B. 2003a: Sedimentološke raziskave srednje in zgornjejurskih kamnin Slovenskega jarka v profilu Zapoškar. - Geološki zbornik-povzetek referatov, 17, 146-149, Ljubljana.

Rožič, B. 2003 b: Basin margin evolution: Middle and Upper Jurassic succession of Slovenian Basin. - in: Velić, I. (ed.): Abstract book of $22^{\text {nd }}$ Meeting of Sedimentology, 180, Opatija.

Rožič, B. 2006: Sedimentologija, stratigrafija in geokemija jurskih plasti zahodnega dela Slovenskega jarka. - Ph.D. Thesis, 148 pp., University of Ljubljana.

Sarti, M., Bosellini, A. \& Winterer, E.L. 1992: Basin geometry and architecture of a Tethyan Passive Margin, Southern Alps, Italy. - AAPG Mem., 53, 241-258.

Shanmugam, G. 2000: 50 years of the turbidite paradigm $(1950 \mathrm{~s}-1990 \mathrm{~s})$ : deep - water processes and facies models - a critical perspective. - Marine and Petroleum Geology, 17, 235-342.

Stow, D.A.V. \& Johansson, M. 2000: Deepwater massive sands: nature, origin and hydrocarbon implications. - Marine and Petroleum Geology, 17, 145-174, Amsterdam.

Šmuc, A. 2004: Sedimentološke in stratigrafske raziskave jurskih in krednih plasti Julijskih Alp. - Ph.D. Thesis, 168 pp., University of Ljubljana.

Šmuc, A. 2005: Jurassic and Cretaceous Stratigraphy and Sedimentary Evolution of the Julian Alps, NW Slovenia. - Založba ZRC, 98 pp., Ljubljana.

Šmuc, A. \& Goričan, Š. 2005: Jurassic sedimentary evolution of a carbonate platform into a deep-water basin, Mt. Mangart (Slovenian-Italian border). - Rivista Italiana di Paleontologia e Stratigrafia, 111/1, 45-70, Milano.

Tišjar, J., Vlahović, I., Velić, I. \& Sokač, B. 2002: Carbonate Platform Megafacies of the Jurassic and Cretaceous Deposits of the Karst Dinarides. - Geologia Croatica, 55/2, 139-170.

Turnšek, D. 1997: Mezosoic Corals of Slovenia. - Založba ZRC, 512 pp., Ljubljana.

Vlahović, I., Tišljar, J., Velić, I., Matičec, D. 2005: Evolution of the Adriatic Carbonate Platform: Paleogeography, main events and depositional dynamics. - Paleogeography, Paleoclimatology, Paleoecology, 220, 333-360.

Weissert, H. \& Mohr, H. 1996: Late Jurassic climate and its impact on carbon cycling. - Palaeogeogr., Palaeoclim., Palaeoecol., 122, 27-43, Amsterdam.

Winterer, E.L. 1998: Paleobathymetry of Mediterranean Tethyan Jurassic pelagic sediments. - Mem. Soc. Geol. It., 53, 97-131, Roma.

Winterer, E.L. \& Bosellini, A. 1981: Subsidence and sedimentation on Jurassic passive continental margin, Southern Alps, Italy. - AAPG Bulletin, 65, 394-421, Tulsa.

Wright, V.P. \& Burchette, T.P. 1996: Shallow-water carbonate environments. - in: Reading, H.G. (ed.): Sedimentary Environments: Processes, Facies and Stratigraphy, 395-453, Blackwell Science, Oxford.

Zempolich, W.G. \& Erba, E. 1999: Sedimentologic and chemostratigraphic recognition of third-order sequences in resedimented carbonate: the Middle Jura-ssic Vajont Limestone, Venetian Alps, Italy. - in: Harris P.M., Saller, A.H. \& Simo, J.A. (eds.): Advances in Carbonate Sequence Stratigraphy: Application to Reservoirs, Outcrops and Models. - SEPM Special Publication, 63, 335-370, Tulsa. 